\title{
Okul Müdürleri, Öğretmenler ve Yardımcı Personelin Okullardaki Örgütsel İletişim İklimine Yönelik Görüsşleri
}

DOI: 10.26466/opus.602779

\author{
Funda Eryılmaz Ballı* - Özgür Önen** \\ * Arş Gör., Süleyman Demirel Üniversitesi, Eğitim Fakültesi, Isparta / Türkiye \\ E-Posta: fundaballi@sdu.edu.tr \\ ORCID: 0000-0003-4703-3945 \\ ** Dr. Öğr. Üy, Burdur Mehmet Akif Ersoy Üniversitesi, Eğitim Fakültesi, Burdur/ Türkiye \\ E-Posta: ozguronen@mehmetakif.edu.tr \\ ORCID: $0000-0002-3715-7488$
}

$\ddot{O} z$

İletişimin en yoğun yaşandığı örgütler arasında yer alan eğitim kurumlarında öğrenciler, öğretmenler, yöneticiler ve diğer paydaşlar sürekli olarak etkileşim ve iletişim içerisindedir. Okulların etkililiği için tüm iletişim kaynaklarının en verimli şekilde kullanılması gerekmektedir. Örgütte çalışanların örgütsel iletişim süreçlerine yönelik duygu, düşünce ve algılarından oluşan örgütsel iletişim iklimi eğitim örgütlerindeki iletişime yön veren etmenler arasında yer almaktadır. Bu araştırmada okul müdürleri, öğretmenler ve yardımcı personelin görev yaptıkları okullardaki örgütsel iletişim iklimine yönelik görüşlerini derinlemesine belirlemek amaçlanmıştır. Nitel bir çalışma olan bu araştırma 5 okul müdürü, 5 öğretmen ve 5 yardımcı personel ile gerçekleştirilmiştir. Veriler yarı yapılandırılmış görüşme tekniği ile elde edilmiş ve içerik analizi yapılmıştır. Araştırma sonucunda katılımcıların güven, açıklık (aşă̆ı yönlü iletişimde), dinleme isteğ $i$ (yukarı yönlü iletişimde) ve yüksek performansh hedeflere dikkat boyutlarındaki paylaşımlarının daha açık ve olumlu, ortak karar verme ve dürüstlük boyutlarında ise daha kapalı ve olumsuz bir iletişim iklimini işaret eder yönde olduğu tespit edilmiştir.

Anahtar Kelimeler: Örgütsel iletişim iklimi; okulda iletişim iklimi; örgütsel iletişim; örgüt iklimi 


\title{
The Views of Principals, Teachers and Support Staff on Organizational Communication Climate in Schools
}

*

\begin{abstract}
Schools are one of the organizations in which communication is most intense. Students, teachers, administrators and other stakeholders are constantly interacting and communicating in educational institutions. For the effectiveness of schools, all communication resources should be used in the most efficient way. Organizational communication climate, which consists of emotions, thoughts and perceptions of the employees about organizational communication processes, is one of the factors that shape the communication in educational organizations. In this study, it is aimed to determine the views of school principals, teachers and support staff on organizational communication climate in schools. The study group of this research, which is a qualitative study, was conducted with the participation of 5 school principals, 5 teachers and 5 support staff. Data was obtained by semi-structured interview technique and content analysis was performed. Findings suggest that the participants' ideas about trust, openness in downward communication, ability to listen in upward communication and attention to high-performance goals dimensions indicate more positive and open organizational communication climate when they indicate more negative and close organizational communication climate about joint decision-making and honesty dimensions.
\end{abstract}

Keywords: Organizational communication climate; communication climate in school; organizational communication; organizational climate 


\section{Giriş}

İnsanların örgütlerde yaptığı işlerin çoğu, bir dereceye kadar aktif işbirliği ve başkalarıyla iletişim kurmayı gerektirir (Kraut, Fish, Root ve Chalfonte, 1990). Hem formal hem de informal kanallar aracılığıyla iletişim, herhangi bir örgütün can damarıdır. İletişimle ilgili tüm bileşenlerin özünde insanlar yer almaktadır. Örgütlerde insanlar oluşturdukları iletişim ağları sayesinde bilgi paylaşımlarında bulunurlar (Buchholz, 2001).

Örgütsel iletişim, bir örgütteki paydaşların amaçları gerçekleştirmek adına aralarında oluşması gereken işbirliğini inşa edecek, örgüte ve çevreye uyumlarını sağlayacak, biçimsel veya biçimsel olmayan formlarda anlama sahip her türlü paylaşımlarıdır (Karakoç, 1989). Örgütte iyi bir iletişim sisteminin varlığ 1 yönetsel süreçlerin işleyişini kolaylaştırmada etkili olmaktadır. İletişimin anlaşılması ve iyileştirilmesi, eşitsizliklerin giderilmesinde kilit rol oynamaktadır (Wynia, Johnson, McCoy, Griffin ve Osborn, 2010). Bunun yanında iyi bir örgütsel iletişim sistemi örgütün psikolojik yönüne de olumlu anlamda hizmet etmekte, gerek örgüt içi gerekse örgüt dışı uyumu kolaylaştırmaktadır (Karcıoğlu, Timuroğlu ve Çınar, 2009). Örgütsel iletişim, işgörenlerin performansına etki eden önemli bir durumsal faktördür (Abdussamad, 2015). Benzer şekilde örgütsel iletişimin örgüt kültürü üzerinde etkisini ortaya koyan çalışmalar mevcuttur (Durğun, 2006; Şomăcescu, Barbu ve Nistorescu, 2016). Ayrıca örgütsel iletişim örgütsel adalet (İçerli, 2010; Doğan, 2002), örgütsel güven (Öktem, Kızıltan ve Öztoprak, 2016) ve örgütsel bağlılık (Bayram, 2005) kavramları üzerinde etkili olabilmektedir. İş doyumu (Karcıoğlu, Timuroğlu ve Ç1nar, 2009; Aktaş ve Şimşek, 2015) da örgütsel iletişimle ilişkili kavramlardan biridir.

Örgütler için bu derece önemli bir kavram olan örgütsel iletişimin olumlu örgütsel sonuçlar doğurabilmesi bu kavramın çalışanlarca nasıl algılandığına yani örgütsel iletişim iklimine bağlıdır. Örgüt ikliminin önemli bir bileşeni olarak örgüt iklimini etkileyen (Nordin, Sivapalan, Bhattacharyya, Ahmad, ve Abdullah, 2014) ve örgütteki etkililik üzerinde kilit rol oynayan (Hassan, Maqsood ve Riaz, 2011) örgütsel iletişim iklimi örgütte çalışanların örgütsel iletişim süreçlerine yönelik duygu, düşünce ve algılarından oluşur. 
Pace ve Faules'a (2013) göre örgütsel iletişim iklimi, iletişim olayları, insan davranışı, üyelerin diğer üyelere verdikleri karşılıklar, beklentiler, kişilerarası çatışmalar ve örgütün büyümesi için fırsatların bir birleşimidir (Ayundhasurya ve Kurniawan, 2018). Örgüt kimliğini etkileyen bir öge (Bartels, Pruyn, De Jong ve Joustra, 2007) olan örgütsel iletişim iklimi, iletişim ortamındaki örgüt ikliminden farklıdır; çünkü iletişim iklimi, organizasyonda meydana gelen mesajların ve mesajla ilgili olayların algılanmasını içerir (Ahsanul, 2013). Dennis'e (1974) göre bir örgütün iç çevresinin özniteliği olan tecrübe kalitesini ifade eden bu kavram, organizasyonda meydana gelen mesajlara ve mesajlarla ilgili olaylara ilişkin üyelerin algı raporları ile tanımlanabilen genel bir çıkarım eğilimi kümesini kapsar. Bir bölgedeki fiziksel ikliminin o bölgedeki yaşamı etkilemesine benzer bir şekilde, bir örgütün iletişim iklimi işgörenlerin kimle konuştuklarını, kimden hoşlandıklarını, nasıl hissettiklerini, ne kadar sıkı çalıştıklarını, ne kadar yenilikçi olduklarını, ne yapmak istediklerini, örgütle ne kadar uyumlu göründüklerini kısaca, işgörenlerin örgütte yaşama şeklini etkiler. Çalışma koşullarının algılanması, denetim, tazminat, terfi, meslektaşlarla ilişkiler, organizasyon kuralları ve düzenlemeleri, karar alma uygulamaları, mevcut kaynaklar ve örgütün üyelerini motive etme yolları bir araya gelerek örgütsel iletişim ortamı olarak adlandırdığımız kavrama dair bilgiler bütününü oluşturur (Ahsanul, 2013). Falcione ve Herden'e (1987) göre iletişim iklimi bir makro imgedir, örgütsel iletişim denilen küresel bir olgunun özetidir. Örgütsel iletişim iklimi, örgütsel tutumlar ile bireysel algılar ya da tutumlar arasındaki etkileşimle gelişir ve bir örgütte daimi olma eğiliminde olan karakterlerin algılanmasından kaynaklanan öznel deneyimlerin kalitesi olarak görülmektedir (Abdussamad, 2015). Kısaca bu kavram bir örgütteki işgörenlerce paylaşılan açıklık, seslilik / sessizlik ve ciddiye alınma algılarını yansıtır (Smidts, Pruy ve Van Riel, 2001).

Örgütsel iklim, çalışanların örgütün fiziksel düzeni, örgütteki paydaşların etkileşim şekilleri ve örgüt üyelerinin diğer paydaşlarla yürüttüğü ilişki ve davranışlara yönelik genel duygu ve düşünceleri ifade eder (Luthans, 2010). Örgütsel iletişim iklimi ise çalışanların organizasyon içinde bilgi alışverişinin etkililiğine dair algılarıdır (Wilson, Dejoy, Vandenberg, Richardson ve Mcgrath, 2004). İletişim iklimi, belirli bir durumda ve belli 
bir zamanda, bir kuruluşun üyelerinin iletişim fenomenlerine yönelik öznel görüşleri, yorumları ve memnuniyetidir. Anlamlarda ve değerlerde tezahür eden iletişim iklimi, bireylerin gözlem, duygu ve değerlerinin bir araya gelmesi ve bir iletişim sisteminin çalışma sürecinin sonucudur (Tukiainen, 2001). Bu bağlamda örgütsel iletişim ikliminin örgüt ikliminin iletişimle ilgili önemli bir bileşeni olduğu ve örgütsel iletişimin sonucu doğrultusunda iletişime yönelik bakışı ortaya koyduğu söylenebilir.

Pace ve Faules (2001) bir örgütün iletişim iklimini analiz etmek için, kullanılabilecek altı ana faktörü şöyle ifade etmiştir: (1) güven, (2) ortak karar verme, (3) dürüstlük, (4) açıklık (aşağı yönlü iletişimde), (5) dinleme isteği (yukarı yönlü iletişimde), ve (6) yüksek performanslı hedeflere dikkat (Abdussamad, 2015; Ayundhasurya ve Kurniawan, 2018);

Güven: Örgütün tüm seviyelerindeki üyeler, güvenilir ilişkiler, inançlar ve söylemler ve eylemlerle desteklenen türde bir güvenilirlik geliştirmek ve sürdürmek için çaba göstermelidir.

Ortak karar verme: Örgütün tüm seviyelerindeki üyelerle, örgüt politikasının tüm alanlarındaki tüm konularda özellikle uzmanlık alanları doğrultusunda iletişim kurulmalı ve onlara danışılmalıdır. Örgüt üyelerine, sürece katılabilmeleri için üstlerindeki yönetim ile iletişim kurma ve danışma fırsatı verilmelidir.

Dürüstlük: Genel bir dürüstlük ve açılık atmosferi, organizasyon içindeki tüm ilişkilerde olmalıdır ve üyeler, akranları, astları veya üstleriyle konuşurken karşılarındakinin hiyerarşik seviyesine bakmaksızın, zihinlerinde ne olduğunu söyleyebilmelidir.

(Aşağı doğru iletişimde) Açıklık: Aşağı doğru iletişim, yöneticiden veya liderden astlara mesajların akışını gösterir. Gizli bilgiler dışında, örgüt üyelerinin mevcut görevleriyle doğrudan ilgili bilgileri elde etmesi nispeten kolay olmalıdır. Çünkü bu durum işlerini koordine etme yeteneklerini ve örgütle ilgili her şeyi etkiler. 
(Yukarn yönlï iletişimde) Dinleme isteği: Yukarı doğru iletişim, alt düzey işgörenden lidere veya bir üst seviyedeki işgörene geçen bir mesajdır. Örgütün tüm seviyelerindeki üyeler, başkalarının önerilerini veya kuruluş içindeki alt seviyedeki diğer üyelerin ortaya çıkardığı sorunlarla ilgili paylaşımları sürekli olarak ve açı fikirli bir şekilde dinlemelidir. Astlardan gelen bilgiler, aksi belirtilmedikçe, uygulanabilecek kadar önemli olarak değerlendirilmelidir.

Yüksek performanslı hedeflere dikkat: Örgütün tüm seviyelerindeki üyeler, yüksek verimlilik, yüksek kalite ve düşük maliyetle sonuçlanan yüksek performanslı hedeflere bağlılık göstermelidir. Bu hedeflerin tüm üyeleri için önem taşıdığ1 ve hepsini ilgilendirdiği unutulmamalıdır.

Bilgi özgürce aktığında örgütsel iletişim iklimi açık; bilgi engellendiğinde ise kapalı olarak tanımlanmaktadır. Açık bir iletişim ikliminde, çalışanlar görüşlerini bildirmekten, şikâyette bulunmaktan ve üstlerine önerilerde bulunmaktan çekinmez. Çalışanlar kendi aralarında önemli kararlar ve kararların uygulanma süreci, personel veya pazarlama kaygıları gibi konular hakkında serbestçe konuşurlar. Bilgi örgüt boyunca yukarı, aşağı ve yatay olarak bozulma olmadan geçer. Araştırmalar bu açık iletişim ikliminin destekleyici, katılımcı ve güven verici olmak üzere en az üç farklı özelliğe sahip olduğunu göstermektedir (Buchholz, 2001).

Kapalı örgütsel iletişim ikliminde iletişim engelleri ortaya çıkar ve bu engeller bireylerin olumsuz geçmiş deneyimlerinden kaynaklanmaktadır. Bireylerin doğası ve önceki yaşantıları değerlerini, inançlarını, düşüncelerini, tutumlarını ve beklentilerini şekillendirir. İşgörenler yetersizlik hissiyle savunma engellerinin arkasına saklanabilirler. Örneğin, egoları eleştiriye tahammül edemeyen çalışanlar, onları kişisel eleştiriye maruz bırakacak türde bilgileri paylaşmazlar. Görüşlerini dile getirmeyi reddederler, iyileştirme için önerilerinde bulunmazlar, inisiyatif almazlar, proje ekiplerine önderlik etmezler (Buchholz, 2001).

Altmışlı yılların başlarında Gibb (1961) iletişimi destekleyici ve savunmacı şeklinde sınıflandırmış (Alexander, 1973) sonra bu sınıflandırma örgütsel iletişim ikliminde iletişim türünü sınıflandırmak için kullanılmaya devam etmiştir. Teşvik edici ve anlayışlı bir ortamda serbestçe paylaşılan bilgilerin oluşturduğu (Forward, Czech ve Lee, 2011) destekleyici iklim- 
deki davranışsal karakterleri Gibb (1961) açıklama, sorun yönelimi, kendiliğindenlik, empati, eşitlik ve geçicilik şeklinde sınıflandırmıştır. Örgütte çalışanların bir tehdit algıladığı ya da hoşlanmadığı bir davranışla karşılaştığında sergilediği iletişimi savunmacı iletişim olarak nitelendiren Gibb (1961) savunma iletişim ikliminde ise değerlendirme, kontrol, strateji, tarafsızlık, üstünlük ve kesinlik olmak üzere altı çeşit davranışsal karakter olduğunu belirtmiştir (Al-Kahtani ve Allam, 2015).

Örgütte bilgi paylaşımının temel ögeleri arasında yer alan iletişim ikliminin (Van Den Hooff ve De Ridder, 2004) yönetimsel hiyerarşiye, her seviyede üyeler arasında örgütsel amaçların uygulanmasına ve uyumuna doğrudan etkisi vardır (Falcione, Sussman, \&Herden, 1987; Poole, 1985; Trujillo, 1983, Akt., Redmond, 2006).

Olumlu bir örgütsel iletişim iklimi yönetsel uygulamaların ve rehberliğin daha destekleyici olmasını sağlar (Ahsanul, 2013). Ayrıca işgörenlerin örgütle özdeşim düzeyi de örgütsel iletişim ikliminden etkilenmektedir (Bartels, Pruyn, De Jong ve Joustra, 2007; Smidts, Pruy ve Van Riel, 2001). Bunlarla beraber örgütsel iletişim değişimi ilan etmek ve açıklamak için bir araç olarak kullanıldığından kuruluşlardaki değişimin başarılı bir şekilde yerleştirilmesinde çok önemli bir rol oynamaktadır (Bharadwaj, 2014). Bu bağlamda olumlu örgütsel iletişim iklimi ile değişim yönetimini daha etkili k1labilmektedir (Mallah, 2016). Etkin iletişim becerileri, örgütsel ve kişisel çatışmalarla başa çıkmada en yararlı araç olabilir. Yani örgütsel iletişim iklimi örgütteki çatışmalar ve çatışma yönetiminde de etki sahibidir (Nordin, Sivapalan, Bhattacharyya, Ahmad, ve Abdullah, 2014). İyi ve etkili bir iletişim iklimi işgörenlerin performans ve motivasyonunu olumlu yönde etkilemektedir (Nurlita, 2012). Örgütsel iletişim iklimi, çalışanlar arasında yatay, yukarı veya aşağı yönlü iletişimi desteklemesi durumunda bütün olarak örgüt iklimini de olumlu yönde etkilemektedir (Nordin, ve diğ., 2014).

Ünler, Kılıç ve Çıray (2014) bankacılık alanında 182 katılımcı ile gerçekleştirdikleri "İletişim ikliminin, iş doyumu ve işden ayrılma niyeti ilişkisine etkisi" başlıklı araştırmalarında iş doyumu ve iletişim ikliminin işten ayrılma niyeti ile olumsuz ilişki içinde olduğu sonucuna ulaşmışlardır. Ayrıca olumlu iletişim iklime sahip örgütlerde işgörenlerin işten ayrılma niyetlerinin azaldığı belirtmişlerdir. Bunun yanında iletişim ikliminin yönetici-çalışan iletişimi ve iletişimde şeffaflık ve güven boyutlarının, 
dışsal kaynaklı iş doyumu ve işten ayrılma niyeti ilişkisi üzerinde etkili olduğunu tespit etmişlerdir.

Krivonos (1978) araştırmasında örgütlerde içsel - dışsal motivasyonun örgütsel iletişim iklimi ilişkisini incelemiş ve içsel motivasyona sahip bireylerin örgütsel iletişim iklimi algılarının dışsal motivasyona sahip bireylerin örgütsel iletişim iklimi algılarından daha farklı olduğunu ortaya koymuştur.

Van Den Hooff, ve De Ridder (2004) grupsal ve örgütsel düzeyde bilgi paylaşımını hangi faktörlerin destekleyip hangilerinin engellediğini ortaya koymak adına gerçekleştirdikleri araştırmalarında, örgütsel iletişim iklimi, örgütsel adanmışlık ve bilgi paylaşımı arasında girift bir ilişki olduğunu ortaya koymuşlardır.

Bölgesel bir polis teşkilatının çeşitli örgütsel seviyelerinde, örgütsel iletişim ikliminin ve algılanan dış prestijin örgütsel kimliklendirme üzerindeki etkisini araştırmak için 314 katılımcı ile gerçekleştirdikleri araştırmalarında Bartels, Pruyn, De Jong ve Joustra (2007) örgütsel iletişim iklimi ile örgütsel kimlik arasındaki açık bir pozitif ilişki olduğu sonucuna ulaşmışlardır.

Nordin, Sivapalan, Bhattacharyya, Ahmad, ve Abdullah (2014) çatışma yönetimi stilleri ile örgütsel iletişim iklimi ilişkisini araştırdıkları çalışmalarında örgütteki çatışma yönetimi stillerinin örgütsel iletişim iklimi alg1ları üzerinde etkili olduğunu ortaya koymuşlardır.

Abdussamad (2015) örgütsel iletişim ikliminin çalışanların performansı üzerinde etkisini araştırdığı çalışmasında örgütsel iletişim ikliminin çalışan performansı üzerinde (\%22.7) önemli bir etkisi olduğunu ortaya koymuştur.

Suudi Arabistan Krallığı, Salman Bin Abdulaziz Üniversitesi'nin alt kadroları arasında rol çatışması üzerine destekleyici ve savunmacı iletişim ortamının katkısını ve ilişkisini araştırdıkları çalışmalarında Al-Kahtani ve Allam (2015) rol çatışmalarının olumsuz örgütsel iletişim ikliminden kaynaklandığını ortaya koymuşlardır.

Örgütsel iletişim ikliminin örgütsel iletişim tatmini üzerindeki etkisini analiz etmek amacıyla, Endonezya'da kâr amacı gütmeyen bir kuruluş olan CIOFF'de gerçekleştirdikleri araştırmalarında Ayundhasurya ve Kurniawan (2018) olumlu iletişim ikliminin iletişim tatminin arttıracağını, artan iletişim tatminin de iş doyumunu olumlu yönde etkileyeceğini ve 
örgüt üyelerinin, görev ve sorumluluklarını doğru bir şekilde yerine getirilmek için büyük bir adanmışlık ve motivasyona sahip olacağını ifade etmişlerdir.

Etkili ve başarılı okullar için ahenkli bir gruba ve etkili bir takım çalışmasına ihtiyaç vardır (Çelik, 2001). İletişim takım etkinliğinin önemli bir unsurudur (İlhan ve İnce, 2015). Takmaz (2009) örgütsel iletişim algıları ile karara katılma davranışları arasındaki ilişkiyi vurgulamış ve karara katılım durumlarının örgütsel iletişim düzeyini etkilediğini belirtmiştir. Dürüst ve açık bir iletişim etkili ve doğru karar almayı sağlayan önemli bir gerekliliktir (Yılmaz, 1999).

Örgütsel iletişim iklimi, etkinliği ve başarıyı arttıran bir kavram olarak örgütler için büyük öneme sahiptir (Nordin ve diğ., 2014). Eğitim kurumları iletişimin en yoğun yaşandığı örgütler arasında yer almaktadır. Öğrenciler, öğretmenler, yöneticiler ve diğer paydaşlar sürekli olarak gerek kendi grupları içerisinde gerekse gruplar arasında etkileşim ve iletişim içerisindedir. Okulların etkililiği için tüm iletişim kaynaklarının en verimli şekilde kullanılması gerekmektedir.

$\mathrm{Bu}$ bağlamda okul müdürleri, öğretmenler ve yardımcı personele önemli roller düşmektedir. Bu çalışanların üstlerine düşeni yapabilmeleri adına okullarındaki örgütsel iletişim iklimine yönelik düşünceleri öncelikli öneme sahiptir. Örgütsel iletişim iklimine yönelik düşünceleri ve bu düşünceleri oluşturan nedenleri tespit etmek, örgütsel iletişim iklimini olumlama adına atılacak ilk adımdır. Bu araştırma bu süreçte etkisi olan paydaşlar için farkındalık oluşturma adına önem taşımaktadır.

Ayrıca ulusal alanyazın incelendiğinde örgütsel iletişim iklimiyle ilgili olarak Taştepe (2005) ve Ünler, Kılıç ve Çıray'a (2014) ait çalışmalar d1şında gerçekleştirilmiş araştırmaya rastlanmamıştır. Araştırmanın bu anlamda da alanyazına katkı sağlayacağı düşünülmektedir.

Amacı Isparta İli merkez ilçede görev yapan okul müdürleri, öğretmenler ve yardımcı personelin görev yaptıkları okullardaki örgütsel iletişim iklimine yönelik görüşlerini derinlemesine tespit etmek olan bu araştırmanın problemini "Okul müdürleri, öğretmenler ve yardımcı personelin okullardaki örgütsel iletişim iklimine yönelik görüşleri nelerdir?" sorusu oluşturmaktadır. Bu araştırmada aşağıdaki alt problemlere cevap aranmıştır: 
1. Okul müdürleri, öğretmenler ve yardımcı personelin görev yaptıkları okullardaki örgütsel iletişim ikliminde "güven" unsuruna yönelik görüşleri nedir?

2. Okul müdürleri, öğretmenler ve yardımcı personelin görev yaptıkları okullardaki örgütsel iletişim ikliminde "ortak karar verme" unsuruna yönelik görüşleri nedir?

3. Okul müdürleri, öğretmenler ve yardımcı personelin görev yaptıkları okullardaki örgütsel iletişim ikliminde "dürüstlük" unsuruna yönelik görüşleri nedir?

4. Okul müdürleri, öğretmenler ve yardımcı personelin görev yaptıkları okullardaki örgütsel iletişim ikliminde "(aşağı yönlü iletişimde) açıklık" unsuruna yönelik görüşleri nedir?

5. Okul müdürleri, öğretmenler ve yardımcı personelin görev yaptıkları okullardaki örgütsel iletişim ikliminde "(yukarı yönlü iletişimde) dinleme isteği" unsuruna yönelik görüşleri nedir?

6. Okul müdürleri, öğretmenler ve yardımcı personelin görev yaptıkları okullardaki örgütsel iletişim ikliminde "yüksek performanslı hedeflere dikkat" unsuruna yönelik görüşleri nedir?

\section{Yöntem}

\section{Araştırmanın Deseni}

Yönetici, öğretmen ve yardımcı personelin okullardaki örgütsel iletişim iklimine yönelik görüşlerini tespit etmek amacıyla gerçekleştirilen bu nitel araştırmada fenomenolojik (olgu bilim) desen kullanılmıştır. Olgu bilim hayatımızda karşılaştığımız ancak detaylı olarak bilgi sahibi olmadığımız ya da üzerinde çok düşünmediğimiz olguları derinlemesine inceleyen nitel çalışma türüdür (Yıldırım ve Şimşek, 2008).

\section{Çalışma Grubu}

Araştırmanın çalışma grubu amaçlı örnekleme yöntemlerinden maksimum çeşitleme yöntemi ile oluşturulmuştur. "Göreli olarak küçük bir örneklem oluşturmak ve bu örneklemde çalışılan probleme taraf olabilecek 
bireylerin çeşitliliğini maksimum derecede yansıtmak" (Yıldırım ve Şimşek, 2008) amacıyla Isparta ili merkez ilçedeki beş okuldan (her bir okuldan bir müdür, bir öğretmen ve bir yardımcı personel olacak şekilde) 5 okul müdürü, 5 öğretmen ve 5 yardımcı personel ile çalışma gerçekleştirilmiştir. Örgütte farklı pozisyonlardaki bireylerin, örgüte dair örgütsel iletişim iklimine yönelik görüşlerinin örgüt iklimine dair daha derinlemesine bilgi vereceği düşüncesiyle bu üç farklı grup seçilmiştir. Katılımcılara ilişkin veriler ve demografik özellikler Tablo 1'de yer almaktadır.

Tablo 1. Katılımcılara ilişkin veriler

\begin{tabular}{lllll}
\hline Katılımc1 & Görev & Cinsiyet & Yaş & K1dem yıl1 \\
\hline M1 & Okul müdürü & E & 50 & 12 \\
\hline M2 & Okul müdürü & E & 40 & 8 \\
\hline M3 & Okul müdürü & E & 35 & 4 \\
\hline M4 & Okul müdürü & $\mathrm{E}$ & 37 & 5 \\
\hline M5 & Okul müdürü & $\mathrm{E}$ & 43 & 9 \\
\hline Ö1 & Öğretmen (Bil.tek) & $\mathrm{K}$ & 37 & 13 \\
\hline Ö2 & Öğretmen (İng) & $\mathrm{K}$ & 35 & 13 \\
\hline Ö3 & Öğretmen (Mat.) & $\mathrm{K}$ & 35 & 12 \\
\hline Ö4 & Öğretmen (Türkçe) & $\mathrm{K}$ & 38 & 15 \\
\hline Ö5 & Ögrretmen (Mat.) & $\mathrm{K}$ & 35 & 15 \\
\hline Y1 & Memur & $\mathrm{K}$ & 33 & 8 \\
\hline Y2 & Memur & $\mathrm{E}$ & 32 & 10 \\
\hline Y3 & Güvenlik görevlisi & $\mathrm{K}$ & 32 & 10 \\
\hline Y4 & Hizmetli & $\mathrm{E}$ & 60 & 21 \\
\hline Y5 & Hizmetli & $\mathrm{K}$ & 38 & 4 \\
\hline
\end{tabular}

\section{Veri toplama araçları}

Araştırma verileri yarı yapılandırılmış görüşme formu kullanılarak bireysel görüşme tekniğiyle elde edilmiştir. Görüşme soruları alanyazın ve önceki araştırmalar doğrultusunda oluşturulmuş ve uzman görüşüne başvurulduktan sonra son halini almıştır. Verilerin toplanması için Milli Eğitim Müdürlügünden gerekli izinler alındıktan sonra belirlenen okullarla görüşülüp katılıma gönüllü olan okul müdürleri, öğretmenler ve yardımcı personel ile uygun tarih ve saatler belirlenmiştir. Belirlenen okullara gidilerek uygulama gerçekleştirilmiştir. Veri ve zaman kaybını engellemek adına, katılımcılardan izin alınarak görüşmeler ses kayıt cihazı ile kayıt 
altına alınmış daha sonra araştırmacı tarafından yazılı metine dönüştürülmüştür.

\section{Verilerin Analizi}

Araştırmada elde edilen veriler içerik analizi ile çözümlenmiştir. Gözlem ve görüşme verilerinin analizinde son derece değerli olan içerik analizi, bir konuyu ve/veya konuyu tanımlayan bilgileri elde etme de çok kullanışlı bir yöntemdir (Fraenkel ve Wallen, 2009). İçerik analizi süreci ham verilerin eşzamanlı olarak kodlanması ve kodların ilgili özelliklerini yakalayan kategorilerin oluşturulmasını kapsar (Merriam, 1998). Bu doğrultuda araştırmacı metne döktüğü ses kayıtlarını incelemiş, kodlar ve bu kodlara uygun kategoriler oluşturulmuştur.

Nicel araştırmalarda geçerlik (validity) ve güvenirlik (reliability) kavramları kullanılırken nitel araştırmalar için Lincoln ve Guba (1981) yine güvenirlik anlamına gelen "inandırıcılık" kavramının kullanımının daha doğru olacağını ifade etmiştir (Akt. Güler, Halıcıoğlu \&Taşğın, 2013). Bu bağlamda nitel araştırmalar için belirlenen dört prensip inandırıcılık (iç geçerlik yerine), transfer edilebilirlik (dış geçerlik yerine), değişmezlik / tutarlık (iç güvenirlik yerine) ve teyit edilebilirliktir (dış güvenirlik yerine) (Erlandson, Harris, Skipper\&Allen, 1993'den Akt. Yıldırım \& Şimşek, 2008). Bu araştırmada çalışma grubunun okullarda görev yapan farklı pozisyonlardaki çalışanlardan (okul müdürü - öğretmen - yardımcı personel) seçilmesi ile çeşitleme yoluna gidilmiştir. Yani farklı özelliklere sahip katılımcılar yoluyla farklı algıların farklı yaşanmışlıkların ortaya konması ve bu yolla inandırıcılığın güçlendirilmesi hedeflenmiştir. Amaçlı örnekleme yoluyla seçilmiş olan çalışma grubu veri kaynaklarının farklı11ğını yansıtabileceğinden transfer edilebilirliğin de sağlanması amaçlanmıştır. Ayrıca görüşmeler yazıya aktarıldıktan sonra katılımcı teyidi alınmış, kodlar ve temalar iki araştırmacı tarafından ayrı ayrı oluşturularak kararlaştırıldıktan sonra benzeşim oranının yeterli düzeyde olduğu görülmüş ve doğrudan alıntılara yer verilmiş bu yolla tutarlık düzeyi arttırılmaya çalışılmıştır.

Araştırma sürecinde içerik analizi sonucunda elde edilen veriler düzenlenmiş sonrasında tablolar yardımıyla sunulmuş ve elde edilen bulgular yorumlanmıştır. 


\section{Bulgular ve Yorum}

\section{Güven}

Güven kategorisi altında beş tema ve toplam 45 koda ulaşılmıştır. Bu kategoriye ilişkin tema ve kodlar Tablo 2'de sunulmuştur. Tablo 2 incelendiğinde, katılımcılar güven oluşturma sürecinde daha çok paydaşların birbirini farklı olaylarla tartmasının etkili olduğunu belirtirken, güvenin korunmasında güvenin ilişkilere dayalı olmasını vurgulamışlardır.

Tablo 2. Güven kategorisine ilişkin tema ve kodlara dair frekans dağılımı

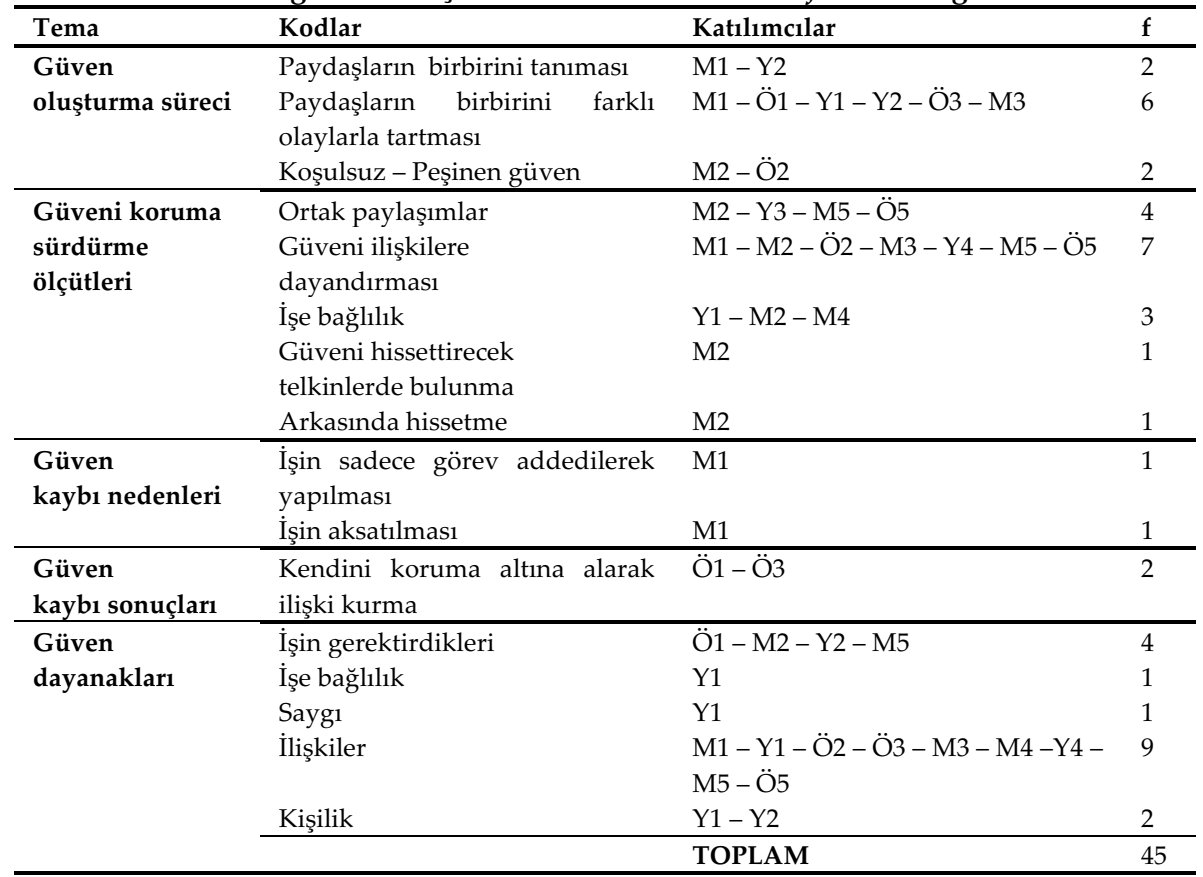

Tablo 2'ye göre güven oluşturma sürecinde bazı katılımcılar paydaşların birbirini zamanla tanıması ve birbirini farklı olaylarla tartması gerektiğini savunurken, bazıları ise en baştan koşulsuz bir güvenin gerekliliğini yaşanmışlıklar sonunda bu güvenin kuvvetlenebileceğini ya da azalabileceğini ifade etmişlerdir. Katılımcılara göre işin sadece görev addedilerek 
yapılması ya da işin aksatılması güven kaybına neden olabilmektedir. Yaşanan güven kaybı sonucunda kendilerini koruma altına alma ihtiyacı duyduklarını belirten katılımcılar bulunmaktadır. İşin gerektirdikleri, işe bağlllık, saygı, ilişkiler ve kişilik güvene temel sağlayacak dayanaklar olarak belirtilen unsurlardır.

Katılımcıların güven ile ilgili görüşlerine dair bazı örneklere aşağıda yer verilmiştir:

“...İ̧sin açıkçası güven oluşturma noktasında ilk başta çok büyük sıkıntı yaşadik iletişim çatışmaları, iletişim ile ilgili sıkıntılarımız oldu bir adım onlar bir adım biz gelerek... Başlangıçtaki okulun ilk kurulduğu dönemle şu ankini karşılaştırırsak o güven ortamın ya da iklimi tanımlayacak olursak şu anda istediğimiz düzeyde mi? istediğimiz düzeyde değil ama istenilene yakın düzeyde bir güven ortamı olduğunu düşünüyorum. Birbirimizi tanıdıktan sonra ama ilk geldiğimizde 3 ayda 5 ayda oluşan bir şey değil. Bir-bir buçuk yıl sonra herkes birbirini farkl olaylarla tartarak hani istenilen düzeye yakın bir düzeye geldik..." (M1)

"...Öncelikle hepsine güvenmek zorundayım ki iş yapayım. Ben hepsine en başta güveniyorum hiç tanımasam da güveniyorum. Güven kaybı sonradan yaşanıyor yani. Bir hizmetli ile olan ilişkimde mesela onun bir işi yapabileceğini düşünerek okul boyutunda düşünürsek iş anlamında bu işi yapabileceğini düşünüyorum. Ona güveniyorum o güveni veriyorum. Sen bu işi yaparsın görevi veriyorum adam da bu güvenin karşılı̆̆ında kendisini sorumlu olarak hissediyor müdür bana güveniyor ben bu işi yapayım diyor. Bunu ben daha sonra diğer arkadaşlara da uygun herkese güven verdiğin zaman daha kolay iş yaptıra biliyorsun onlara sadece verme anlamında değil öyleymiş gibi davranmak da değil aslında biz onlara nasıl davranıyoruz gerçekten güveniyoruz ilk başta bir avans veriyoruz onlar onu azaltıyor ya da değerlendirip çoğaltıyor. Ilk baştan şüphe ile baksak iş yapamayız zaten tam tersi olur adama hiç güvenmezsen sürekli takip etsen bu işi yaptı mı yapmadı mı yani şüpheye düşersen bu sefer bir problem oluşur. Kafasında müdür bana zaten güvenmiyor. O zaman işte her şeyde denetlenme ihtiyacı duyuyor ama ben koşulsuz güveniyorum yaptıkları ile ilgili ..." (M2)

“...Belli bir kesimde yaşadığın bazı olaylar neticesinde o güven olayı maalesef kırlliyor ve daha seviyeli daha kendini koruma altına alarak bir ilişki kurmak zorunda kaliyorsun..."(Ö1)

“...Genel anlamda güven var bu güven bireysel ilişkiler kaynakll, okul ortamında tecrübeye dayalı olarak yaşananlardan dolayı özellikle devlet kurumlarında 
daha da dikkatli olmak zorunda kalıyorsunuz kelimeleri özenle seçip kullanıyorsunuz. Genel anlamda olumlu sayılır ama yine de insanlarn tedbirli olduğu bir ortam var diyebiliriz..." (Ö3)

“...Güven olmadığında çalışılmaz zaten... Genel anlamda kişiye bakıyorum ben tanımak lazım sonuçta tabii... Yani insanları tanımadan da tam olarak güven olmaz güven olmadan da kurumda çalışılmaz zamanla yaşadıklarım güven ortaminı oluşturuyor işte ..." (Y2)

\section{Ortak karar verme}

Tablo 3. Ortak karar verme kategorisine ilişkin tema ve kodlara dair frekans dağılımı

\begin{tabular}{|c|c|c|c|}
\hline Tema & Kodlar & Katılımcılar & $\mathbf{f}$ \\
\hline \multirow[t]{2}{*}{ Karar katılım } & İstişare edilmesi & $\mathrm{M} 1-\mathrm{M} 2-\mathrm{O} 2-\mathrm{M} 3-\mathrm{Y} 3-\mathrm{M} 5-\mathrm{Y} 5$ & 7 \\
\hline & Toplantılarda fikir sorma & $\mathrm{Y} 1-\mathrm{O} 2-\mathrm{M} 3-\mathrm{M} 4-\ddot{\mathrm{O}} 4-\mathrm{M} 5-\ddot{\mathrm{O}} 5$ & 7 \\
\hline \multirow[t]{2}{*}{ Karar merci } & İlk söz yönetim & $\mathrm{Y} 1$ - Ö3 - Y3 - Y4 - M5 - Ö5 - Y5 & 7 \\
\hline & Son söz yönetim & M2 - Ö3 - M5 - Ö5 - Y5 & 5 \\
\hline \multirow[t]{3}{*}{ Karar Konuları } & $\begin{array}{l}\text { Öğretmenlere danışılacak ko- } \\
\text { nular }\end{array}$ & M1 & 1 \\
\hline & $\begin{array}{l}\text { Yönetimin karar alması gere- } \\
\text { ken konular }\end{array}$ & M1 - Y3 - M5 - Ö5 - Y5 & 5 \\
\hline & Uzmanlık gerektiren konular & $\mathrm{M} 1-\mathrm{M} 2-\mathrm{Y} 3$ & 3 \\
\hline \multirow[t]{5}{*}{$\begin{array}{l}\text { Katılımı etkile- } \\
\text { yen faktörler }\end{array}$} & $\begin{array}{l}\text { Fikirleri kendine saklama eği- } \\
\text { limi }\end{array}$ & Ö1-Ö4-M5 & 3 \\
\hline & Yaşanmışlıkların etkisi & Ö1 - Ö3 & 2 \\
\hline & Arkanın sağlam olması & Ö1 & 1 \\
\hline & Paylaşımların sonuçları & Ö1 & 1 \\
\hline & & TOPLAM & 42 \\
\hline
\end{tabular}

Ortak karar verme kategorisi altında dört tema ve toplam 42 koda ulaşılmıştır. Bu kategoriye ilişkin tema ve kodlar Tablo 3'te sunulmuştur. Tablo 3 incelendiğinde katılımcıların karara katılım sürecinin birebir istişare etme ve toplantılarda fikir sorma şeklinde gerçekleşebildiğini belirtmişlerdir. Karar alınacak bir konuda kararı en başta zaten yönetimin verdiğini ya da danışılsa dahi son sözü yönetimin verdiğini ifade eden katılımcılar da bulunmaktadır. Ayrıca öğretmenler, yaşanmışlıkların etkisinin ve kişilerin fikirlerini paylaşma ya da kendine saklama yönündeki eğilimlerinin karara katılmalarını etkileyen faktörler olduğunu paylaşmışlardır.

Her ne kadar danışılıyor olsa ya da danışılıyormuş gibi görünse de katılımcıların görüşleri genel olarak değerlendirildiğinde, paylaşımlarının 
kararı pek fazla etkilemediği ya da göz ardı edildiği ve karar verilecek konunun kendi yetki ve yeterliklerini aştığı düşüncesi sebebiyle fikirlerini paylaşmakta istekli olmadıkları görülmektedir. Buna göre katılımcıların görüşleri örgütlerinde ortak karar vermeye yönelik olarak kapalı ve olumsuz bir örgütsel iletişim ikliminin olduğu yönündedir.

Katılımcıların ortak karar verme ile ilgili görüşlerine dair bazı örneklere aşağıda yer verilmiştir:

“...Öğretmenler kurulumuz var iki dönem başında ve yllsonunda gerçekleşiyor herkes eteğinde ne varsa hepsini döker bir yıl boyunca neler yapildrysa yılsonundaki toplantıda değerlendirilir yılbaşında da neler varsa yapılabilecek onlar fikirlerini açıklarlar. Kararı alırız o kararı uygulamaya çalışırız ortak olarak alınır kararlar ve herkesin oyuna sunulur onaylanırsa karar defterine yazllır..." (M4)

“... İki şık arasında kendim karar veriyorum artık yani böyle çoğunluk değişik şeyler çıktı̆̆ı zaman herkesin fikri ayrı yirmi kişiyi aynı noktada her zaman birleştiremiyorsun. Ha birleştiremediğin zaman çoğunluğun fikirlerini alarak sen kendin karar veriyorsun..." (M2)

"...Okul müdürü kararı alır ama beraber karar alınıyormuş gibi yapılır, güya bize sorulur ama aslinda sorulmuyor, haber veriliyordur, yani tek karar merci aslında müdürdür..." (Ö3)

“...Biz toplantı yapmadan bazı arkadaşlarla karar verip onların toplantıda iyidir bu demesini să̆lıyoruz. Biri zaten iyi değdiği zaman... Grup liderlerini yönetmek gerekiyor... Oradan birkaç kişi iyi dediği zaman diğerleri zaten hemen düşüncesini o yöne yaklaştırıyor. Ama eğer olumsuz bir düşünce ortaya çıkarsa sonra o olumsuz düşünceyi yenme şansımız yok. O zaman otoriterliğinizi devreye sokuyorsunuz ama okulumuzda buna özen gösteriyoruz yapacağımız şeyleri birçok arkadaşla birebir istişare ediyoruz. Çünkü toplu istişarede bir yerlere varam-yoruz, toplumsal kültürümüzden dolayı varamıyoruz toplulukta konuşmaya yönelik bir çekinti var..." (M5)

“... Toplantılarda genelde beraber karar alıyoruz ama tabii ki idarenin de zaman zaman hani şöyle yapılmalı böyle yapılmalı dediği ya da zaten idarenin karar vermesi gereken konular oluyor. Onlarla ilgili kararlarn alıyorlar toplantıda bu hepimize bildiriliyorlar..." (Ö5)

“...Kendi adıma yaptığımız toplantılarımızda ben çok söz hakkı almam. Yaşadı̆̆ım olaylar neticesinde böyle bir duruma geldik maalesef. İşte ilk tabii ki tanışma sürecinde evet kendi fikirlerini beyan ediyorsun ama aldığın tepkiler neti- 
cesinde diyorsun ki ben fikrimi beyan etmemeliyim. Çünkü ben fikrimi paylaşırsam zor durumda kalabiliyorum diyorsun. Toplantılarda fikir beyan etmiyorum ben mesela..." (Ö1)

\section{Dürüstlïk}

Dürüstlük kategorisi altında dört tema ve toplam 24 koda ulaşılmıştır. Bu kategoriye ilişkin tema ve kodlar Tablo 4 'te sunulmuştur. Tablo 4 incelendiğinde katılımcıların çoğunlukla paydaşların duygu, düşünce ve ihtiyaçlarını açıkça dile getirildiğini belirttiği görülmektedir. Katılımcılar kendisi dürüst davrandığı için karşısındakilerin de kendine dürüst davrandıkları, paydaşların samimiyet durumlarının değişkenlik gösterdiği ve okullarda grupların bulunduğu yönünde paylaşımlarda bulunmuşlardır.

Tablo 4.Dürüstlük kategorisine ilişkin tema ve kodlara dair frekans dağılımı

\begin{tabular}{llll}
\hline Tema & Kodlar & Katılımcılar & f \\
\hline Açıklık yaşantıları & Duygu - düşünce - ihtiyaçların açıç̧a dile & M1-Ö1-Y1-M2 & 6 \\
& getirilmesi & - Ö4-Y4 & \\
& Duygu - düşünce - ihtiyaçların açıç̧a dile & M1 - Ö3 - M4 - & 4 \\
& getirilememesi & Ö5 & \\
& Sessiz kalmayı tercih etme & Ö1-Ö4-Y5 & 3 \\
\hline \multirow{2}{*}{ Farklı profiller } & Her çeşit insanın var olduğu bir yapı olmas1 & M1 & 1 \\
& Grupların mevcut olması & M1 - M5 & 2 \\
\hline Karşılıklı olma durumu & Dürüstüm - dürüstsün & M3-Y4 & 2 \\
\hline Samimiyet & Herkesin samimi olmaması & M1-M4 & 2 \\
& Herkesin samimi olması & Ö2-Y2 & 2 \\
& Arkadaşlık ilişkisine bağlı olma & Ö2-Ö5 & 2 \\
\cline { 2 - 4 } & & TOPLAM & 24 \\
\hline
\end{tabular}

Dürüstlük kategorisine ait analiz sonuçlarına göre katılımcı görüşleri genel olarak değerlendirildiğinde katılımcıların görev yaptıkları örgütteki dürüstlük yaşantılarına dair daha kapalı ve olumsuz bir örgütsel iletişim iklimi algısına sahip oldukları söylenebilir.

Katılımcıların dürüstlük ile ilgili görüşlerine dair bazı örneklere aşağıda yer verilmiştir:

“...Söylenenle söylenmek istenen farklı olabiliyor, yanlış anlamalar olup yorum katılıp başka yerlere başka şekilde aktarmalar olabiliyor. O yüzden kişisel 
ilişkilerimizin kuvvetli olduğu insanlarla birebirde daha rahat konuşabilirken genel görüş sorulan özellikle yönetimin de bulunduğu ortamlarda daha özenli cümlelerle iletişim kurmaya özen gösteriyoruz..." (Ö3)

“...Bulunduğumuz ortamda dürüst olmak zorunda insanlar birbirine devlet kurumundayız işin doğru yapılması için dürüstlük şart. Ben burada çalıştığım süre boyunca sıkıntı yaşamadım herkesin dürüst olduğunu düşünüyorum samimiyetten doğan dürüst bir ortam var. Bizim okulumuzda bence bana göre samimi dürüst bir ortam oluştu herkes genç, geneli genç bir kadro var güzel bir ortam var..."(Y2)

“...Diyorum ya sonucu kötü olacak bile olsa olumsuz olacak bile olsa düşüncelerimden vazgeçmem. En kötü ihtimal nedir fikrimi beyan etmem yani yalan ya da yanlış bir şey ifade etmektense düşüncemi hiç belli etmem sessiz kalmayı tercih ederim..." (Ö1)

“...Tabii şu an 60 kişiyiz biz. Bunun 52-53 tanesi öğretmen. Karma bir okul burası çok farklı insan grubunun olduğu görüş olarak da tutum olarak da gelişmişlik hayata bakış açısı olarak da çok farklı profillerin olduğu bir okul... Dürüstlük durumu da farklllık gösteriyor..."(M1)

“...Burada düşüncelerimizi açıkça rahatça söyleyebiliriz onlar da bize söyle söyler. Ben dürüstsem karşımdaki de dürüst davranır ..." (Y4)

“...Çoğunluğun gerçek düşüncelerini paylaştığını sanmıyorum ama ben iletişimimin iyi olduğunu düşünüyorum. Ben kendi açımdan dürüst olmaya çalışıyorum, arada onlardan da geri dönütler oluyor ancak belki de herkesle aynı samimiyette olmamamız nedeniyle tam karşılığı bulabildiğimizi düşünmüyorum..." (M4)

“...Paylaşımlar kiş̧iye göre değişiyor arkadaşlık ilişkin daha iyiyse kolay ama bazı kişiler o eleştiriyi kabul edecek düzeyde olmadığı için söyleyemiyorum, söyleyemediğim çok oluyor bazen üstü kapalı hani ima oluyor..." (Ö5)

\section{Açıklık}

Açılık kategorisi altında üç tema ve toplam 33 koda ulaşılmıştır. Bu kategoriye ilişkin tema ve kodlar Tablo 5 'te sunulmuştur. Tablo 5 incelendiğinde katılımcıların hepsinin görevleri sebebiyle mecburi paylaşımların sorunsuzca gerçekleştiği yönünde görüş bildirdiği görülmektedir. Bunun 
yanında katılımcılar ihtiyaç duyulan diğer belge ve bilgilere de çoğunlukla sorunsuz erişildiği ve genelde aşağıya yönelik paylaşımların açık, net ve anlaşılır şekilde olduğunu belirtmişlerdir.

Tablo 5.Açıklık kategorisine ilişkin tema ve kodlara dair frekans dağılımı

\begin{tabular}{|c|c|c|c|}
\hline Tema & Kodlar & Katılımcilar & f \\
\hline \multirow[t]{2}{*}{ Açıklık kaynağı } & Astın yaptığı işe güvenme & Ö1 & 1 \\
\hline & $\begin{array}{l}\text { Pozisyon gereği mecburi } \\
\text { paylaşımlar }\end{array}$ & $\begin{array}{l}\mathrm{M} 1-\ddot{\mathrm{O}} 1-\mathrm{Y} 1-\mathrm{M} 2-\ddot{\mathrm{O}} 2-\mathrm{Y} 2- \\
\mathrm{M} 3-\ddot{\mathrm{O}} 3-\mathrm{Y} 3-\mathrm{M} 4-\ddot{\mathrm{O}} 4-\mathrm{Y} 4- \\
\mathrm{M} 5-\mathrm{Ö} 5-\mathrm{Y} 5\end{array}$ & 15 \\
\hline Verilen mesaj niteliği & Açık - net - anlaşılır & $\mathrm{Y} 1-\mathrm{M} 2-\mathrm{O} 2-\mathrm{Y} 2-\mathrm{M} 5$ & 5 \\
\hline Belge - bilgi erişimi & Sorunsuz erişim & $\begin{array}{l}\mathrm{M} 1 \text { - Ö1 - Y1 - M2 - Ö2 - Ö3 - } \\
\mathrm{M} 3-\mathrm{M} 4-\mathrm{O} 4-\mathrm{Y} 4-\mathrm{M} 5 \text { - Ö5 }\end{array}$ & 12 \\
\hline TOPLAM & & & 33 \\
\hline
\end{tabular}

Tablo 5'e göre katılımcıların genel olarak bulundukları örgütte aşağı doğru iletişimde açıklığa yönelik olumlu görüşlere sahip olduğu örgütlerindeki örgütsel iletişim iklimini açıklık boyutunda olumlu olarak değerlendirdikleri söylenebilir.

Katılımcıların açıklık ile ilgili görüşlerine dair bazı örneklere aşağıda yer verilmiştir:

“...Sıkıntı yok yaptığım işe güveniyorlar ve benim o işteki becereme de güveniyorlar Dolayısıyla sıkıntı yaşamadan istediğim belge ya da bilgilere ulaşabiliyorum..." (Ö1)

“...Onlardan beklediklerimi açık ve net bir biçimde ilk başta konuştuk zaten. Yani herkesin görevi var. Ne diyelim ki derse zamanında girmek biraz önce söyledim ya bu herkesin kendi görevi zaten biz bunu üstüne basa basa okula ilk adım attığımızda ilk toplantımızda açık açık söyledik. Görev ve sorumluluklar yerine getirilirse ne olacağını getirilmezse ne olacağını tek tek konuştuk tartıştık bunları artık tekrar söylememe gerek yok, herkes biliyor..." (M2)

“...Açık olarak bizden beklentilerini bizimle paylaşır zaten paylaşılması da lazım herkes görev ve sorumluluklarmı bilir, bilmeli tabii müdürün de bu sorumlulukların yerine getirilmesini beklemesi doğaldır yani. Ve herkesin de sorumluluklarını yerine getirmesi lazım. Ben net olarak görevimi biliyorum. Burada nasıl yapacă̆̆mı nasıl bir işleyiş yapacă̆ımı biliyorum ona göre çalışıyorum işlerimi tamamliyorum kafam rahat oluyor bu şekil..."(Y2)

"...Yapılacak işin açık ve net bir biçimde faydasını önemini anlatıyoruz karşımızdakine ne yapması gerektiğini anlatıyoruz buna ikna olursa zaten işi yapıyor 
gönüllü olarak yapıyor isteyerek yapıyor daha etkili oluyor. Dışarıdan gelenler de önce yadırgıyorlar sonra ortama uyum sağhlyorlar akıllarına yatıyor..." (M5)

\section{Dinleme İste ği}

Dinleme isteği kategorisi altında beş kategori ve toplam 22 koda ulaşılmiştır. Bu kategoriye ilişkin tema ve kodlar Tablo 6'da sunulmuştur. Tablo 6 incelendiğinde katılımcıların yönetimin fikirlere saygilı olduğunu ve önyargısız yaklaştığını, paylaşılanları sakladığını ve paylaşılanlara paylaşımın okula katacakları doğrultusunda değer verdiğini belirttikleri görülmektedir. Bununla beraber paylaşımların uygulanabilirliğinin makullüğe, okul kültürüne ve yasa, yönetmelik ve mevzuata uygunluğa bağlı olduğu görüşünü paylaşmışlardır.

Tablo 6. Dinleme isteği kategorisine ilişkin tema ve kodlara dair frekans dağılımı

\begin{tabular}{|c|c|c|c|}
\hline Tema & Kodlar & Katılımcılar & $\mathrm{f}$ \\
\hline \multirow[t]{2}{*}{ Yaklaşım } & Yönetimin fikirlere saygılı olması & Ö2 - Ö5 & 2 \\
\hline & Yönetimin önyargısız yaklaşması & $\mathrm{Y} 1$ - Ö2 - M3 & 3 \\
\hline Gizlilik & Yönetimin paylaşılanları saklaması & Ö2 - Y2 - Y3 & 3 \\
\hline \multirow[t]{2}{*}{ Erişim } & Yönetimin kolay erişilebilir olması & Y1 & 1 \\
\hline & Yöneticiye erişimin değişkenlik göstermesi & Ö3 & 1 \\
\hline Uygulanabi- & Fikir ve önerilerin makullüğü & M1 - M5 - Y5 & 3 \\
\hline \multirow[t]{3}{*}{ lirlik } & Fikir ve önerilerin okul kültürüne uygunluğu & M1 & 1 \\
\hline & $\begin{array}{l}\text { Fikir ve önerilerin yasa- yönetmelik - } \\
\text { mevzuata uygunluğu }\end{array}$ & $\mathrm{M} 2-\mathrm{M} 3-\mathrm{Y} 3-\mathrm{M} 5$ & 4 \\
\hline & Fikir ve önerilerin konusu & Y2 & 1 \\
\hline Değer & Fikir ve önerilerin okula katacakları & M4 - Ö4 - Ö5 & 3 \\
\hline TOPLAM & & & 22 \\
\hline
\end{tabular}

Tablo 6'ya göre katılımclların genel olarak bulundukları örgütte paylaşımların dinlenmesine ve paylaşılanlara yaklaşıma yönelik olumlu görüşlere sahip olduğu, örgütlerindeki örgütsel iletişim iklimini dinleme isteği boyutunda olumlu olarak değerlendirdikleri söylenebilir.

Katılımcıların dinleme isteği ile ilgili görüşlerine dair bazı örneklere aşağıda yer verilmiştir:

“...Rahatça konuşabilirler çünkü insanları konuştuklarından dolayı kesinlikle yargılamam. Sen yanlış düşünüyorsun, senin düşündüğ̈̈̈n yanlış, bunu nasıl uygulayabiliriz şeklinde cümleler kurmam çünkü benim için karşı taraf ya da 
farklı değerler her zaman değerlidir. Benim hayat felsefem budur. Bin bilsem dahi birbirinin fikrini alırım Bu yüzden böyle olduğunu bildikleri için arkadaşlar rahatça gelip benimle paylaşır..." (M3)

“...Normal bir problem olabilir kişisel probleminiz olabilir işle ilgili olabilir burada yaşadıklarınız ile ilgili olabilir gönül rahatlı̆̆ ile gidip iletişim kurabiliriz. Bizi dinlerler, bizi destekleyeceklerine inanıyorum ve biliyorum da zaten. En başından beri son derece rahat bir iletişimimiz var anlattıklarımızın korunacă̆ına yönelik her zaman güven veriyorlar açıkça duygumuzu düşüncemizi paylaşabiliyoruz..." (Ö2)

“... İdareye erişim idarecinin ruh haline bağhldır. Bazen çekinerek gidersin çok rahat karşılar şaşırırsın, bazen de çok sinirli olur kapıdan girmek istemez dönersin çünkü sinirliyken ciddi anlamda ters tepki verebiliyor..." (Ö3)

“...Ĕ̆ger söylediğiniz fikirler gerçekten onların da aklına yatıyorsa ki bu hepimiz için geçerli, olumlu bir anlamda izlenim bırakıyorsa, makulse, değerlendirirler uygulamaya da koyarlar..." (Y5)

“...Biz fikir paylaşacak yeni bir şeylerle gelecek öğretmenleri dört gözle bekliyoruz. Bence hangi yönetici olursa olsun böyle, gelen öğretmeni ters karşılayacağın sanmıyorum. İhtiyacımız var bizim onlara. Yöneticinin görevi zaten okulu daha iyi bir seviyeye getirmek herkesi mutlu - memnun etmek yeni bir fikir demek yeni bir açılım demek yenilik demektir. Bütün idareciler bence destek olur..." (M4)

\section{Yüksek performanslı hedeflere dikkat}

Yüksek performanslı hedeflere dikkat kategorisi altında iki tema ve toplam 20 koda ulaşılmıştır. Bu kategoriye ilişkin tema ve kodlar Tablo 7' de sunulmuştur.

Tablo 7. Yüksek performansl hedeflere dikkat kategorisine ilişkin tema ve kodlara dair frekans dağılımı

\begin{tabular}{|c|c|c|c|}
\hline Kategori & Kodlar & Katılımcılar & $\mathrm{f}$ \\
\hline Hedeflere & Yükü sırtlayanlar & M1 - Ö3-M4-Ö4-M5-Ö5 & 6 \\
\hline yönelik & Tüm paydaşların çaba sarf etmesi & Ö1 - Y1 - Ö2 - Y2 - Y3 - Y4 - Y5 & 7 \\
\hline emek & Suya sabuna dokunmayanlar & M1 - Ö3 - M4 - Ö4 - Ö5 & 5 \\
\hline \multirow{2}{*}{$\begin{array}{l}\text { Hedef oluş- } \\
\text { turma }\end{array}$} & Tüm paydaşlarla koyulan hedefler & M2 & 1 \\
\hline & Kalıp hedefler (akademik) & M3 & 1 \\
\hline TOPLAM & & & 20 \\
\hline
\end{tabular}


Tablo 7'de katılımcıların bulundukları örgütte yüksek performanslı hedeflere dikkat edilmesine ve bu yönde çaba sarf edilmesine yönelik olarak farklı yönde görüşler bildirdikleri görülmektedir. Öğretmen ve okul müdürü olan katılımcıların bir kısmı okulun performans değerlerini arttırmak için yalnızca belli bir grup öğretmenin çaba sarf ettiğini bütün yükü onların taşıdığını vurgularken, yine benzer şekilde diğer bir kısmı da okulda bir grup öğretmenin rutin bir şekilde derse girip çıkmak dışında çaba sarf etmediklerini belirtmişlerdir. Bunun tersine yardımcı personel olarak görev yapan katılımcıların tümü okuldaki tüm paydaşların ciddi bir çaba sarf ettiğini, performansı arttırmak için hep beraber hedeflere yönelik emek verdikleri yönünde görüş bildirmişlerdir. Katılımcıların yüksek performanslı hedeflere dikkat ile ilgili görüşlerine dair bazı örneklere aşağıda yer verilmiştir:

“...Okulu daha iyi bir pozisyona getirmek tüm öğretmenlerin amacı bu. Daha iyi ne yapabiliriz? Daha iyi konuma okulu nasıl getirebiliriz? Öğrenciler için daha verimli nasıl olabiliriz? Hep bunun çabası içindeler herkes. Herkes buna gönülden bağhl. Güzel olan tarafi da bu zaten tüm öğretmenler de ayn gayret ve çaba var. Tabii belki biraz da genç olmanın getirdiği potansiyel hep genç çünkü. Daha fazla ne yapabiliriz? Hep bunun çabası içerisindeler. Hep bunu tartışıp konuşuyorlar. İ̧eride de hiç kimsenin boş oturduğunu görmüyorum birbirleriyle de hep iletişim halindeler böyle zümre olarak da gidip birbirlerine soruyorlar. Şunu yapalım mı bunu yapalım mı?..." (Ö2)

“...Hedeflere bağlllık tabii ki yüksek seviyede ama hedeflerin derler ya gerçeklik ya da uygulanabilirlik kısmı önemli. Ben burada şunu söyleyeceğim genelde hedefler başarıya dönük başarıya odaklı başarıya odaklı hedefleri olduğu için sadece bu hedefi ön planda tutup diğer değerler eğitimi olsun ahlak toplum kuralları olsun diğer hedefler geri planda kalınca arkadaşlar bu konuda rahatsızlık duyuyor. Hani okumuş değerlerine bağh olmayan bireyler yetiştirmek topluma zarar veriyor biz görüyoruz bunu. Bunu görüp ve bildiğimiz için sadece akademik anlamda hedeflere odaklanmamaya çalışıyoruz..."(M3)

“...Hedeflere sıkı sıkıya bağhı olup uygulayanlar da var tam tersi de var. \%50 - \%50 bu durum bireysel performansla ilgili bence görev bilinciyle ilgili. Öğretmenlik bir giysiyi giymeye benzer, kıyafeti giyersin bazısına çok yakışır çok iyi taşır ki bu da mesleğin gerekliliklerini yerine getirmeyle işine dair her şeyi güzelce yapmasıyla ilgili, kimisine de hiç yakışmaz eğreti durur üstünde..." (Ö3) 
“...Yani çoğu şöyle diyeyim her meslekte olduğu gibi mesleğini standart yapan ya da mesleğini bir üst noktaya taşımaya çalışan arkadaşlar muhakkak var ama yine de geneli elinden geldiğince canla başla çalışırlar..." (M4)

“...belli Bir grup arkadaş var sürekli bir şeyler yapma çabasındalar. Sadece ders değil dersin dışında da sürekli bir faaliyet içerisindeler. Hani bir altmış kişi içerisinde on beş yirmi kişi böyle söyleyebiliriz. Gece gündüz sürekli ne yapabiliriz ne oluşturabiliriz... Bu arkadaşlarm sayesinde hani Okulumuzun birkaç senedir biraz ilerlemesinde de o arkadaşların katkısı olduğunu düşünüyorum. Belli bir grupta da hani ben dersime girerim çıkarım görevimi yaparım o anlayıştalar..." (Ö4)

“...Biz bu hedefleri beraber koyduk... Öğretmenin de aklına yattığı için hatta bizden de daha fazla olarak yeni fikirlerle gelip bir şeyler yapmak istiyorlar ortak olarak bir hedefe bağlandık biz ciddi anlamda bir performans sergiliyor herkes bu yüzden..." (M2)

Genel olarak değerlendirildiğinde katılımcıların güven, açıklık, dinleme isteği ve yüksek performanslı hedeflere dikkat boyutlarındaki paylaşımları daha açık ve olumlu bir örgütsel iletişim iklimini işaret ederken, ortak karar verme ve dürüstlük boyutlarında daha kapalı ve olumsuz bir iletişim iklimini işaret etmektedir.

\section{Tartışma, Sonuç ve Öneriler}

Okul müdürleri, öğretmenler ve yardımcı personel örgütsel iletişim ikliminin güven boyutunda güven oluşturma sürecinde daha çok paydaşların birbirini farklı olaylarla tarttığını, güveni koruma ya da sürdürmede güvenin ilişkilere dayandırıldığını ve örgütteki ilişkilerin güven oluşturmadaki önemini vurgulamışlardır. Katılımcıların genel olarak bulundukları örgütte güven ortamına yönelik olumlu görüşlere sahip olduğu, örgütlerindeki örgütsel iletişim iklimini güven boyutunda olumlu olarak değerlendirdikleri söylenebilir. Nitekim çok sayıda araştırmacı, kişilerarası ve grup davranışını, yönetimsel etkinliği, ekonomik değişimi ve sosyal veya politik istikrarı anlamak için, insanlar arası ilişkilerdeki yeri oldukça kritik olan temel duygular arasında yer alan güven olgusunun (Asunakutlu, 2011) önemini vurgulamaktadır. İnsan ilişkileri kadar eskiye dayanan (Tokgöz ve Seymen, 2013) güven kavramını Golembiewski ve McConkie (1975) de kişilerarası ve grup davranışını tamamen etkileyen 
tek değişken olarak nitelendirmiştir (Hosmer, 1995). Bu bağlamda bu kadar önemli bir olgu olan güvenin eğitim kurumlarında tesisi konusunda bütün paydaşların gereken özeni göstermesi gerekmektedir.

Okul müdürleri, öğretmenler ve yardımcı personel okuldaki karar alma sürecine yönelik olarak istişare edilmesi ve toplantılarda fikir sorulması yoluyla karara katılım gösterdiklerini ancak bazı durumlarda son sözü yine yönetimin söylediğini belirtmişlerdir. Bazı katılımcılar yönetimin aslında herhangi bir konuda aslında zaten en başında bir karar aldıklarını diğer paydaşların fikrine de "başvuruluyormuş gibi" yaptıklarını vurgulamışlardır. Bunun yanında alınacak kararın konusunun da süreçte etkili olduğunu ve bazı kararları yönetimin alması gerektiğini söyleyen katılımcılar olmuştur. Her ne kadar danışılıyor olsa ya da danışılıyormuş gibi görünse de katılımcıların görüşleri genel olarak değerlendirildiğinde, paylaşımlarının kararı pek fazla etkilemediği ya da göz ardı edildiği ve karar verilecek konunun kendi yetki ve yeterliklerini aştı̆̆1 düşüncesi sebebiyle fikirlerini paylaşmakta istekli olmadıkları görülmektedir. Buna göre katılımcıların görüşlerinin örgütlerinde ortak karar vermeye yönelik olarak kapalı ve olumsuz bir örgütsel iletişim iklimini işaret ettiği söylenebilir. Karara katılım örgüt üyelerinde sahiplik duygusunu, gönüllülüğü ve sorumluluk almayı arttıran bir faktördür (Demirtaş ve Alanoğlu, 2015). Örgütlerde başarı için insan faktörünün, ortak akıl yürütme, toplam kalite yönetimi ve öğrenen örgüt gibi kavramların ön plana çıktığı günümüzde, örgütlerin çalışanlarının yenilikçi fikir ve farklı bakış açılarından faydalanmasının gerekliliği ortadadır (Bakan ve Büyükbeşe, 2008). Tüm paydaşların karara katılımı hususunda örgütsel bir politikanın varlığı eğitim kurumları için olumlu sonuçlar doğurabilecek bir yaklaşım olabilir.

Okul müdürleri, öğretmenler ve yardımcı personel okuldaki dürüstlük boyutuna yönelik olarak bazı okullarda paydaşların genellikle okullarda duygu, düşünce ve ihtiyaçlarını açıkça dile getirebildiklerini belirtirken bazı katılımcılar görev yaptıkları okullarda bunları açıça dile getiremeyen paydaşların çoğunlukta olduğunu, bazıları da paydaşların eğiliminin sessiz kalma yönünde olduğunu belirtmişlerdir. Okullarda farklı grupların bulunması, kendisi dürüst olduğu için karşı tarafın da dürüst yaklaştığ1 ve arkadaşlık ilişkisinin dürüstlükte bir kriter olduğu düşünceleri de paylaşımlar arasında yer almaktadır. Dürüstlük kategorisi analiz sonuçlarına göre genel olarak değerlendirildiğinde katılımcıların görev yaptıkları 
örgütteki dürüstlük yaşantılarına dair görüşlerinin daha kapalı ve olumsuz bir örgütsel iletişim iklimine işaret ettiği söylenebilir. Dürüstlük olguların gerçekliğinin olduklarından farklı olduğunu iddia etmeyi reddetmektir ve ekstra durumlar haricinde rasyonel bir insanın çıkarınadır (Becker, 1998). Çeşitli nedenlerle gerçek düşünceleri açıkça paylaşamamak çalişanlarca bir tür engellenme olarak algılanabilir. Engellenmenin yoğun olarak hissedilmesi örgüt çalışanlarının kendini çaresiz hissederek geri çekilmesine ya da öfke veya saldırganlı̆̆a neden olabilmektedir (Varoğlu, 2013). Okullarda gerek örgütsel gerekse psikolojik boyutlarda olumlu yaşantılara sahip olunabilmesi için tüm paydaşların kendilerini dürüstçe ifade edebilecekleri, bu ifadeler sonunda ortaya çıkan farklılıklara saygıyla yaklaşılan, daha özgür ve önyargısız ortamlara ihtiyaç duyulmaktadir.

Açıklık boyutunu oluşturan unsurlardan oluşan belge, bilgi paylaşımı konusunda okul müdürleri, öğretmenler ve yardımcı personelin neredeyse tamamı erişimin sorunsuz olduğunu ve genellikle evrak ve bilgi paylaşımlarının Milli Eğitim Müdürlüğü kaynaklı olduğunu ve birçoğunun zaten zorunlu olarak kendileriyle paylaşıldığını belirtmişlerdir. Bunun yanında yönetimden gelen mesajların açık, net ve anlaşılır olduğu görüşüne sahip katılımcılar mevcuttur. Katılımcıların genel olarak bulundukları örgütte aşağı doğru iletişimde açıklığa yönelik olumlu görüşlere sahip olduğu örgütlerindeki örgütsel iletişim iklimini açıklık boyutunda olumlu olarak değerlendirdikleri söylenebilir. Açı iletişimin etkililiği birçok örgütsel teorisyen ve araştırmacı tarafından kabul edilmektedir. Bilgi saklama ya da eksik bilgilendirme bazı problemlerin zamanla büyümesine ve/veya yönetilebilir olmaktan çıkmasına sebep olabilmektedir (Eisenberg ve Witten, 1987). İş doyumunu destekleyen bir etmen olarak iletişimde açıklık (Trombetta ve Rogers, 1988) örgütsel performans üzerinde etkilidir aynı zamanda sorunların erken tespitine, çözüme yönelik erken girişimlere ve çözüm yelpazesini genişletmeye olanak sağlar (Rogers, 1987). Bilgi ve belge paylaşımının gerekli olduğu şekilde sağlandığı bir örgüt ortamı gelişime, daha güvenilir bir örgüt ortamı oluşmasına, iletişim kanallarının daha etkili çalışmasına ve örgütsel öğrenme hızına olumlu anlamda katkı sağlayacaktır (Barutçugil, 2002a). Bu bağlamda eğitim örgütlerinde özellikle aşağı doğru iletişimde açıklık yani yönetimin iletmek istediği mesajlarda açık net ve anlaşılır olması ve paydaşların 
mevcut görevleriyle doğrudan ilgili bilgileri elde etmesini kolaylaştırması gerekmektedir.

Dinleme isteği boyutunda ise okul müdürleri, öğretmenler ve yardımcı personelin geneli yönetime sunulan fikir ve önerilerin uygulanabilirliğinin fikir ve önerilerin yasa- yönetmelik ve mevzuata uygunluğu, makullüğü ve okul kültürüne uygunluğuyla, değerinin ise fikir ve önerilerin okula katacaklarıyla paralel olduğunu belirtmişlerdir. Yönetimin paylaşılanları saklaması, fikirlere saygılı olması ve önyargısız yaklaşması da paydaşların paylaşımlarında rol oynayan faktörler arasında yer almaktadır. Katılımcıların genel olarak bulundukları örgütte paylaşımların dinlenmesine ve paylaşılanlara yaklaşıma yönelik olumlu görüşlere sahip olduğu, örgütlerindeki örgütsel iletişim iklimini dinleme isteği boyutunda olumlu olarak değerlendirdikleri söylenebilir. Nitekim özellikle yirminci yüzyılın ortalarından itibaren, işletme uzmanları tarafından oldukça arzu edilen bir örgütsel beceri olarak gösterilen etkili dinleme aynı zamanda örgütsel imajın karakteristik özelliklerden biridir (Flynn, Valikoski ve Grau, 2008). Yöneticilerin dinleme becerilerinin özellikle paydaşların örgütsel adanmışlığı üzerinde olumlu etkileri bulunmaktadır (Bambacas ve Patrickson, 2008). Değişim ve gelişimin hizla gerçekleştiği ve rekabetin yoğun olarak yaşandığı yirmi birinci yüzyıl örgütler için paydaşlarla iletişimi geliştirmeyi zorunlu kılmıştır. Artık örgütlerin, paydaşları aktif olarak dinlemesi ve astlardan gelen mesajları doğru şekilde değerlendirip cevaplayabilmesi ve kullanabilmesi hayati önem taşımaktadır (Burnside-Lawry, 2012). Bu bağlamda okul yöneticilerinin diğer paydaşların paylaşımlarını aktif olarak dinlemeleri, yeni fikir ve önerilere önyargısız yaklaşmaları, paydaşlara özgürce paylaşımda bulunabilecekleri ortamları yaratmaları eğitim kurumlarının etkililiğinde rol oynayabilecek unsurlar olarak değerlendirilmektedir.

Yüksek performanslı hedeflere dikkat boyutunda yardımcı personelin tamamı okuldaki tüm paydaşların çaba sarf ettiğini belirtirken, okul müdürleri ve öğretmenler paydaşlar arasında bir grubun tüm yükü üstlendiğini ancak sadece rutinleri gerçekleştiren, en alt düzeyde performans sergileyip fazlası için çaba göstermeyen bir grubun da olduğunu vurgulamaktadır. Bunun yanında hedef oluşturma sürecinin de sergilenen performansı etkilediğini belirten katılımcılar mevcuttur. Katılımcıların genel 
olarak bulundukları örgütte yüksek performanslı hedeflere dikkat edilmesine ve bu yönde çaba sarf edilmesine yönelik olumlu görüşlere sahip olduğu, örgütlerindeki örgütsel iletişim iklimini yüksek performanslı hedeflere dikkat boyutunda olumlu olarak değerlendirdikleri söylenebilir. Çalışanların örgütsel hedeflerle özdeşleşmesi örgüte sağlayacakları katkının artışında rol oynayan bir etmendir. Bu bağlamda gerek hedefleri gerekse performans standartlarını ortaya koyarken paydaşların genelinin katılımını sağlamak hedeflere bağlılık ve bunların gerçekleşmesi için gösterilecek çaba adına motive edici unsurlardır (Barutçugil, 2002b). Okullarda hedefler, performans ve performans değerlendirme kriterleri belirlenirken tüm paydaşların görev ve sorumlulukları doğrultusunda sürece dâhil edilmesi ve performans değerlendirme sürecinin layığıyla gerçekleştirilmesi paydaşların performansına dolayısıyla ortak hedeflere ulaşılmasına etki edebileceğinden okul müdürlerinin bu süreci yönetme konusunda daha fazla çaba ve dikkat sarf etmesi gerekmektedir.

Genel olarak değerlendirildiğinde katılımcıların güven, açılık, dinleme isteği ve yüksek performanslı hedeflere dikkat boyutlarındaki paylaşımları daha açık ve olumlu bir örgütsel iletişim iklimini işaret ederken, ortak karar verme ve dürüstlük boyutlarında daha kapalı ve olumsuz bir iletişim iklimini işaret etmektedir.

Etkinliği ve başarıyı arttıran bir kavram olan örgütsel iletişim ikliminin (Nordin ve diğ., 2014) önemini ortaya koyan araştırmaların (Abdussamad, 2015; Al-Kahtani ve Allam, 2015; Ayundhasurya ve Kurniawan, 2018; Bartels, Pruyn, De Jong ve Joustra, 2007; Krivonos, 1978; Nordin, Sivapalan, Bhattacharyya, Ahmad, ve Abdullah, 2014; Ünler, Kılıç ve Çıray, 2014; Van Den Hooff, ve De Ridder, 2004) yanında, örgütsel iletişim ikliminin her bir alt boyutunun örgütler için ayrı ayrı öneme sahip kavramlar olduğu göz önünde bulundurulduğunda, iletişimin en yoğun yaşandığı örgütler arasında yer alan okullarda olumlu örgütsel iletişim ikliminin bir gereklilikten öte bir zorunluluk olduğu söylenebilir. Okullarda etkililik için tüm paydaşların olumlu örgütsel iletişim iklimi oluşturmada üzerine düşeni yapması gerekmektedir. Bulgular, sonuç ve tartışma doğrultusunda aşağıdaki önerilerde bulunulmuştur.

1. Okul yönetimi okullarda karara katılımı sağlamaya yönelik stratejiler geliştirmeli ve daha çok paydaşın kararlara etkin katılımını desteklemelidir. 
2. Okul yönetimi okullarda paydaşların duygu, düşünce ve ihtiyaçlarını açıç̧a dile getirebilecekleri daha saygılı, özgür ve demokratik bir örgüt yapısı oluşturmak için gereken özeni göstermeli bu konuda diğer paydaşlara rol model olmalıdır.

3. Türkiye'de örgütsel iletişim iklimiyle ilgili neredeyse hiç çalışma bulunmaması göz önünde bulundurulduğunda böylesine önemli bir konuyla ilgili daha fazla ve detaylı araştırmalar gerçekleştirilmelidir.

4. Bu çalışmada veri toplama yöntemi olarak bireysel görüşme yöntemi kullanılmıştır. Araştırma gözlem ve daha farklı yöntemlerle desteklenerek farklı çalışma gruplarına uygulanabilir. 


\title{
EXTENDED ABSTRACT
}

\section{The Views of Principals, Teachers and Support Staff on Organizational Communication Climate in Schools}

\author{
* \\ Funda Eryılmaz Ball1 - Özgür Önen \\ Süleyman Demirel University, Mehmet Akif Ersoy University
}

Active cooperation and communication is required to some degree in organizations for the most of the work that people do (Kraut, Fish, Root and Chalfonte, 1990). Communication through both formal and informal channels is the lifeblood of any organization. People are at the core of all communication related components. In organizations, people share information through communication networks they create (Buchholz, 2001).

Organizational communication is the sharing of all kinds of stakeholders in an organization in formal or non-formal forms, which will build the cooperation between them in order to realize their goals, ensure their adaptation to the organization and the environment (Karakoç, 1989).

Organizational communication, which is a very important concept for organizations, has positive organizational results and depends on how this concept is perceived by employees, that is it depends on organizational communication climate. Organizational communication climate that affects organizational climate as an important component of organizational climate (Nordin, Sivapalan, Bhattacharyya, Ahmad, and Abdullah, 2014) and plays a key role on the effectiveness of the organization (Hassan, Maqsood and Riaz, 2011). It consists of emotions, thoughts and perceptions of the employees in organizational communication processes.

Pace and Faules (2001) described six main factors that could be used to analyze the communication climate of an organization: (1) trust, (2) joint decision-making, (3) honesty, (4) openness in downward communication, (5)ability to listen in upward communicatin and (6) attention to high-performance goals (Abdussamad, 2015; Ayundhasurya and Kurniawan, 2018). 
When information flows freely, the climate of organizational communication is open; when information is blocked, it is defined as close.

There is a need for a harmonious group and effective teamwork for effective and successful schools (Çelik, 2001). Communication is an important element of team activity (Illhan and İnce, 2015). Takmaz (2009) emphasized the relationship between organizational communication perceptions and decision-making behaviors and stated that participation in the decision affects the level of organizational communication. Honest and open communication is an important requirement that enables effective and correct decision making (Yllmaz, 1999).

Organizational communication climate has great importance for organizations as a concept that increases efficiency and success (Nordin et al., 2014). Educational institutions are among the organizations with the most intensive communication. Students, teachers, administrators and other stakeholders are constantly interacting and communicating both within and between their groups. For the effectiveness of schools, all communication resources should be used in the most efficient way.

In this context, school principals, teachers and support staff have important roles. In order for these employees to do their part, their ideas about the organizational communication climate in their schools are of primary importance. The first step to be taken in the name of affirmation of organizational communication climate is to determine the thoughts about the organizational communication climate and the reasons that make up these thoughts. This research is important to raise awareness for stakeholders who have an impact on this process.

Phenomenological (phenomenology) design was used in this qualitative research conducted to determine the views of the administrators, teachers and support staff about the organizational communication climate in the schools. The study group of the study was formed with maximum diversity method, one of the purposive sampling methods, and the study was carried out with 5 school principals, 5 teachers and 5 support staff. These three different groups were chosen with the idea that individuals in different positions in the organization would give more in-depth information about the organizational climate.

The research data was obtained by individual interview technique using semi-structured interview form. Interview questions were formulated 
in accordance with the literature and previous researches and were finalized after the expert opinion was consulted. After obtaining the necessary permissions from the Directorate of National Education for the collection of the data, appropriate dates and times were determined with the school principals, teachers and support staff who volunteered to participate in the designated schools. Interviews were made by visiting the designated schools. In order to prevent loss of data and time, the interviews were recorded with a voice recorder and then converted into written text by the researchers.

The data obtained in the research was analyzed by content analysis. The researchers examined the sound recordings they poured into the text, then the codes and the appropriate categories were formed. In this research, the study group was selected from the employees who work in different positions (school principal - teacher - support staff). In other words, it is aimed to reveal different experiences of different perceptions through participants with different characteristics and to strengthen trustworthiness by this way. It is also aimed to transferability by the selected working group which can reflect the diversity of data sources. In addition, after the interviews were transcribed, participant confirmation was obtained, codes and themes were created and compared separately by two researchers and direct quotations were used to increase consistency.

The participants expressed positive ideas about trust, openness in downward communication, ability to listen in upward communication, attention to high performance goals dimensions. According to the results in the joint decision-making dimension, although it seems to be consulted, it is seen that the sharing of the stakeholders does not affect the decision much or is neglected and they are not willing to share their opinions with the idea that the subject matter to be decided exceeds their own competencies and competences. In the honesty dimension, it is seen that the stakeholders have doubts about the honesty of the other stakeholders and they think that they are not honest enough.

Consequently findings suggest that the participants' ideas about trust, openness in downward communication, ability to listen in upward communication and attention to high-performance goals dimensions indicate more positive and open organizational communication climate when they 
indicate more negative and close organizational communication climate about joint decision-making and honesty dimensions.

\section{Kaynakça / References}

Abdussamad, Z. (2015). The influence of communication climate on the employees' performance at government agencies in gorontalo city:An Indonesian case study. Asia Pacific Journal of Multidisciplinary Research, $3(5), 19-27$.

Ahsanul, I. M. (2013). The role of communication climate in organizational effectiveness. International Journal of Scientific and Engineering Research, 4(7), 155-156.

Aktaş, H ve Şimşek, E. (2015). Bireylerin örgütsel sessizlik tutumlarında iş doyumu ve duygusal tükenmişlik algılarının rolü. Uluslararası Yönetim Íktisat ve İşletme Dergisi, 11(24), 205-230.

Alexander, J. F. (1973). Defensive and supportive communications in normal and deviant families. Journal of Consulting and Clinical Psycho$\log y, 40(2), 223-231$.

Al-Kahtani, N. S., ve Allam, Z. (2015). Communication climate as predictor of role conflictamong subordinate staff of Salman Bin Abdulaziz University. Asian Social Science, 11(12), 248.

Asunakutlu, T. (2011). Örgütsel güvenin oluşturulmasına ilişkin unsurlar ve bir değerlendirme. Sosyal ve Beşeri Bilimler Araştırmaları Dergisi, 1(9), 1-13.

Ayundhasurya, D. R. ve Kurniawan, F. (2018). The influence of organizational communication climate on organizational communication satisfaction to non-profit organization CIOFF Indonesia. Bandung Creative Movement (BCM) Journal, 41, 140-144.

Bakan, İ., ve Büyükbeşe, Ö. G. T. (2008). Katılımcı karar verme: kararlara katılım konusunda çalışanların düşüncelerine yönelik bir alan çalışması. Süleyman Demirel Üniversitesi İktisadi ve İdari Bilimler Fakültesi Dergisi, 13(1), 29-56.

Bambacas, M., ve Patrickson, M. (2008). Interpersonal communication skills that enhance organisational commitment. Journal of Communication Management, 12(1), 51-72. 
Bartels, J.,Pruyn, A., De Jong, M., ve Joustra, I. (2007). Multiple organizational identification level sand the impact of perceived external prestige and communication climate. Journal of Organizational Behavior: The International Journal of Industrial, Occupational and Organizational Psychology and Behavior, 28(2), 173-190.

Barutçugil, İ. (2002a). Bilgi yönetimi. İstanbul: Kariyer Developer.

Barutçugil, İ. (2002b). Performans yönetimi. İstanbul: Kariyer Developer.

Bayram, L. (2005). Yönetimde yeni bir paradigma: örgütsel bağlılık. Sayıştay Dergisi, 59,125-139.

Becker, T. E. (1998). Integrity in organizations: Beyond honesty and conscientiousness. Academy of Management Review, 23(1), 154-161.

Bharadwaj, A. (2014). Planning internal communication profile for organizational effectiveness. IIM KozhikodeSociety\& Management Review, 3(2), 183-192.

Buchholz, W. (2001). Open communication climate. Unpublished manuscript, Bentley College Waltham, Massachusetts.

Burnside-Lawry, J. (2012). Listening and participatory communication: A model to assess organization listening competency. International Journal of Listening, 26(2), 102-121.

Çelikten, M. (2001). Etkili okullarda karar süreci. Erciyes Üniversitesi Sosyal Bilimler Enstitüsü Dergisi,1(11), 1-12.

Demirtaş, Z., ve Alanoğlu, M. (2015). Öğretmenlerin karara katılımı ve iş doyumu arasındaki ilişki. Journal of Kirsehir Education Faculty, 16(2), 83100.

Dennis, H. S. (1974). A theoretical and empirical study of managerial communication climate in complex organizations. Yayınlanmamış Doktora Tezi. Xerox Üniversitesi Microfilms, AnnArbor, Michigan.

Doğan, H. (2002). İşgörenlerin adalet algılamalarında örgüt içi iletişim ve prosedürel bilgilendirmenin rolü. Ege Akademik Bakış Dergisi, 2(2), 71-78.

Durğun, S. (2006). Örgüt kültürü ve örgütsel iletişim. Yüzüncü Yıl Üniversitesi, Eğitim Fakültesi Dergisi, 3(2), 112-132.

Eisenberg, E. M., ve Witten, M. G. (1987). Reconsidering openness in organizational communication. Academy of Management Review, 12(3), 418426.

Flynn, J.,Valikoski, T. R., ve Grau, J. (2008). Listening in the business context: Reviewing the state of research. The Intl. Journal of Listening, 22(2), 141-151. 
Forward, G. L.,Czech, K., ve Lee, C. M. (2011). Assessing Gibb's supportive and defensive communication climate: An examination of measurement and constructvalidity. Communication Research Reports, 28(1), 115.

Gibb, J. R. (1961). Defensive communication. Journal of communication, 11(3), 141-148.

Güler, A., Halıcıoğlu, M. B., ve Taşğın, S. (2013). Sosyal bilimlerde nitel araştırma yöntemleri. Ankara: Seçkin Yayıncilık.

Hassan, B.,Maqsood, A. ve Riaz, M. N. (2011). Relationship between organizational communication climate and interpersonal conflict management. Pakistan Journal of Psychology, 42(2), 1-20.

Hosmer, L. T. (1995). Trust: The connecting link between organizational theory and philosophic alethics. Academy of Management Review, 20(2), 379-403.

İçerli, L. (2010). Örgütsel adalet: Kuramsal bir yaklaşım. Girişimcilik ve Kalkınma Dergisi, 5(1), 67-92.

İlhan, A., ve İnce, E. (2015). Takım çalışması ve takım etkinliğini belirleyen faktörlerin ölçülmesi: Gaziantep Üniversitesinde bir uygulama. Kahramanmaraş Sütçü İmam Üniversitesi İktisadi ve İdari Bilimler Fakültesi Dergisi, 5(1), 127-152.

Karakoç, N. (1989). Örgütsel iletişim ve örgütsel zaman arasındaki ilişkiler. Kurgu Anadolu Üniversitesi İletişim Bilimleri Fakültesi Uluslararası Hakemli İletişim Dergisi, 6(6), 81-90.

Karcıoğlu, F., Timuroğlu, K., ve Çınar, O. (2009). Örgütsel iletişim ve iş tatmini ilişkisi bir uygulama. İstanbul Üniversitesi İşletme İktisadi Enstitüsü Dergisi-Yönetim, 67.

Kraut, R. E.,Fish, R. S., Root, R. W., ve Chalfonte, B. L. (1990). Informal communication in organizations: Form, function, and technology. In $\mathrm{Hu}$ man reactions to technology: Claremont symposium on applied social psychology (p. 145-199), Beverly Hills, CA: Sage Publications.

Krivonos, P. D. (1978). The relationship of intrinsic-extrinsic motivation and communication climate in organizations. The Journal of Business Communication (1973), 15(4), 53-65.

Luthans, F. (2010). Organizational behavior. New York: McGraw-Hill. 
Mallah, T. (2016). Creating an organizational climate for communication: internal communication and leadership in a project-based international organization: the case of UNOPS.Unpublished Master's thesis, University of Tampere / School of Communication, Media \& Theatre, Tampere.

Nordin, S. M.,Sivapalan, S., Bhattacharyya, E., Ahmad, H. H. W. F. W., ve Abdullah, A. (2014). Organizational communication climate and conflict management: communications management in an oil and gas company. Procedia-Social and Behavioral Sciences, 109, 1046-1058.

Nurlita, I. (2012). Investigation of organizational communication climate at Bhayangkara Surabaya University using communication climate inventory (CCI) method. Academic Research International, 3(2), 259-264.

Öktem, Ş. ve Kızıltan, B. (2016). Örgütsel güven ile örgüt ikliminin örgütsel özdeşleşme, iş tatmini ve işten ayrılma niyeti üzerine etkileri: otel işletmelerinde bir uygulama. İşletme Araştırmaları Dergisi, 8(4), 162-186.

Pardede, E.,Miraza, B.H., ve Sirojuzilam-Lubisi S. (2014). The analysis of communication climateand organizational culture in improving regional development planner's performance (A case study on Education and Industrial Training Centre, Ministry of Industry Region I, Medan). Asian Journal of Humanities and SocialStudies, 2(3), 410-416.

Redmond, J. W. (2006). Issues in human relations management. In Handbook of media management and economics (p. 125-154). Routledge.

Rogers, D. P. (1987). The development of a measure of perceived communication openness. The Journal of Business Communication (1973), 24(4), 5361.

Smidts, A.,Pruyn, A. T. H., ve Van Riel, C. B. (2001). The impact of employee communication and perceived external prestige on organizational identification. Academy of Management Journal, 44(5), 1051-1062.

Şomăcescu, S. M., Barbu, C. M. ve Nistorescu, T. (2016). Investigating the relationship between organizational communication and organizational culture. Management \& Marketing Journal, 14(1), 91-100.

Takmaz, Ş. U. (2009). Illköğretim okullarında örgütsel iletişim düzeyi ile öğretmenlerin karara katılma davranışı arasındaki ilişki Yayımlanmamış doktora tezi, Selçuk Üniversitesi, Sosyal Bilimleri Enstitüsü. Konya.

Taştepe, S. (2005). Örgütsel iletişim iklimi, yönetimi iletişim iklimi ve iş tatmini arasındaki ilişki. Yayımlanmamış yüksek lisans tezi. Marmara Üniversitesi Sosyal Bilimler Enstitüsü. İstanbul. 
Tokgöz, E. ve Seymen, O.A. (2013). Örgütsel güven, örgütsel özdeşleşme ve örgütsel vatandaşlık davranışı arasındaki ilişki: bir devlet hastanesinde araştırma. Öneri Dergisi, 10(39), 61-76.

Trombetta, J. J., ve Rogers, D. P. (1988). Communication climate, job satisfaction, and organizational commitment: The effects of information adequacy, communication openness, and decision participation. Management Communication Quarterly, 1(4), 494-514.

Tukiainen, T. (2001). An agenda model of organisational communication. Corporate Communications: An International Journal, 6(1), 47-52.

Ünler, E., Kılıç, B., ve Çıray, J. C. (2014). İletişim ikliminin, iş doyumu ve işten ayrılma niyeti ilişkisine etkisi. Marmara Üniversitesi Öneri Dergisi, 11(41), 237-250

Van Den Hooff, B., ve De Ridder, J. A. (2004). Knowledge sharing in context: the influence of organizational commitment, communication climate and $\mathrm{CMC}$ use on knowledge sharing. Journal of knowledge management, 8(6), 117-130.

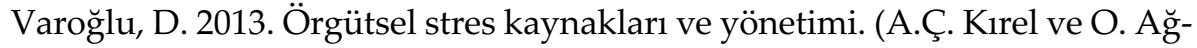
largöz Ed.) Örgütsel Davranış içinde (s. 144-167). Eskişehir: Anadolu Üniversitesi.

Wilson, M. G.,Dejoy, D. M., Vandenberg, R. J., Richardson, H. A., ve Mcgrath, A. L. (2004). Work characteristics and employee health and well-being: Test of a model of healthy work organization. Journal of Occupational and Organizational Psychology, 77(4), 565-588.

Wynia, M. K., Johnson, M., McCoy, T. P., Griffin, L. P., ve Osborn, C. Y. (2010). Validation of an organizational communication climate assessment tool kit. American Journal of Medical Quality, 25(6), 436-443.

Yıldırım, A. ve Şimşek, H. (2008). Sosyal bilimlerde bilimsel araştırma yöntemleri. Ankara: Seçkin Yayıncllı.

Yılmaz, A. (1999). Etkili karar verme süreci: Yeni bir karar verme model önerisi. Kuram ve Uygulamada Eğitim Yönetimi Dergisi, 5(2), 209-220. 


\section{Kaynakça Bilgisi / Citation Information}

Ball1-Eryılmaz, F.. ve Önen, Ö. (2019). Okul müdürleri, öğretmenler ve yardımcı personelin okullardaki örgütsel iletişim iklimine yönelik görüşleri. OPUS-Uluslararası Toplum Araştırmaları Dergisi, 14(20), 514-550. DOI: $10.26466 /$ opus.602779 